\title{
Genetic variability and structure of an isolated population of Ambystoma altamirani, a mole salamander that lives in the mountains of one of the largest urban areas in the world
}

\author{
ROSA-LAURA HEREDIA-BOBADILLA ${ }^{1}$, OCTAVIO MONROY-VILCHIS ${ }^{1 *}$, \\ MARTHA M. ZARCO-GONZÁLEZ ${ }^{1}$, DANIEL MARTÍNEZ-GÓMEZ ${ }^{2}$, \\ GERMÁN DAVID MENDOZA-MARTÍNEZ ${ }^{2}$ and ARMANDO SUNNY ${ }^{1}$
}

${ }^{1}$ Centro de Investigación en Ciencias Biológicas Aplicadas, Universidad Autónoma del Estado de México, Instituto literario \# 100, Colonia Centro, CP 50000 Toluca, Estado de México, México

${ }^{2}$ Departamento de Producción Agrícola y Animal, Universidad Autónoma Metropolitana Xochimilco, Calz. Del Hueso 1100, Col. Villa Quietud, 04960 México, México

*For correspondence. E-mail: omv@uaemex.mx; tavomonroyvilchis@gmail.com.

\begin{abstract}
Amphibians are globally threatened by habitat loss and fragmentation; species within the order Ambystoma are not the exception, as there are 18 species of mole salamanders in México, of which 16 are endemic and all species are under some national or international status of protection. The mole salamander, Ambystoma altamirani is a microendemic species, which is distributed in central México, within the trans-Mexican volcanic belt, and is one of the most threatened species due to habitat destruction and the introduction of exotic species. Nine microsatellite markers were used to determine the genetic structure, genetic variability, effective population size, presence of bottlenecks and inbreeding coefficient of one population of $A$. altamirani to generate information which might help to protect and conserve this threatened species. We found two genetic subpopulations with significant level of genetic structure $\left(F_{\mathrm{ST}}=0.005\right)$ and high levels of genetic variability $\left(H_{\mathrm{O}}=0.883 ; H_{\mathrm{e}}=0.621\right)$; we also found a small population size $\left(N_{\mathrm{e}}=8.8\right)$, the presence of historical $(M=0.486)$ and recent bottlenecks under IAM and TPM models, with a low, but significant coefficient of inbreeding $\left(F_{\mathrm{IS}}=-0.451\right)$. This information will help us to raise conservation strategies of this microendemic mole salamander species.
\end{abstract}

Keywords. population genetics; conservation genetics; microsatellites; microendemic species; threatened species.

\section{Introduction}

Amystoma altamirani is an endemic mountain mole salamander that lives in small, permanent streams which flows in the high mountains in central Mexico in Pinus and Abies religiosa forests. This species occur in isolated populations of the valley of Mexico, in the trans-Mexican volcanic belt (TMVB), at altitudes from 2700 to 3450 masl (meters above sea level) (Lemos-Espinal 2003; Shaffer et al. 2008). The Abies-Pinus forest and the streams in the surrounding area of Mexico city, where this species live, are severely changed, leading to a severely degraded habitat fragmented by agriculture and urban settlements (Lemos-Espinal et al. 1999; Griffiths et al. 2004; FríasÁlvarez et al. 2008; Contreras et al. 2009; Lemos-Espinal et al. 2016; Sunny et al. 2017) and the wooded areas are subjected to illegal logging (FAO 2006; Ellis and PorterBolland 2008; Becker et al. 2016), stream pollution and sedimentation (Shaffer et al. 2008). Also, local people tend to eat molesalamanders (Casas-Andreu et al. 2004) and 


\section{Revised Proof}

Rosa-Laura Heredia-Bobadilla et al.

introduce trout, carp and tilapia farms that predate and compete with mole salamanders, even in protected natural areas (Lemos-Espinal et al. 1999, 2016; Griffiths et al. 2004; Frías-Álvarez et al. 2008; Shaffer et al. 2008; Contreras et al. 2009; Farías-Álvarez et al. 2010). This has eliminated the species from many streams, and many populations showed a severe decline of $>50 \%$ over the last three generations (Shaffer et al. 2008). The environmental vulnerability score of $A$. altamirani is 13 , in a range of $3-19$; this score positions it between medium and high vulnerabilities, primarily because of its restricted geographic and ecological distributions (Wilson et al. 2013; LemosEspinal et al. 2016). Therefore, this species is protected by Mexican law under the 'Special Protection' category and the IUCN categorized this species as endangered (Shaffer et al. 2008; Semarnat 2010). The isolated and fragmented populations by a matrix of agriculture and urbanization, can be considered islands in terms of genetic variability, gene flow and landscape connectivity (Kim et al. 1998; Sunny et al. 2014a). The fragmentation of the habitat and the introduction of exotic species at the landscape scale may reduce connectivity among amphibian populations leading to fragmentation and isolation, which could reduce gene flow and increase the loss of genetic variability through genetic drift and increase the chance of inbreeding (Lande 1998; Frankham et al. 2002, 2005; Beebee and Griffiths 2005; Storfer et al. 2009; Hedrick 2011), bottlenecks and diseases (Frankham et al. 2005) and the probability of local extinctions (Newman and Tallmon 2001; Johansson et al. 2006). Habitat change affects the populations of amphibians and reptiles more than other vertebrate taxa (Jäggi and Baur 1999; Woinarski and Ash 2002; Anadón et al. 2006; Castellano and Valone 2006; Ribeiro et al. 2009; Sunny et al. 2014a, 2015, 2017), owing to their small home ranges, high philopatry and low vagility (Huey 1982; Ribeiro et al. 2009). For these reasons, amphibians are a high priority vertebrate group for which conservation strategies must be carried out (Cushman 2006; Storfer et al. 2009; Allentof and O'Brien 2010; Nori et al. 2015). Therefore, we studied the genetic variability and structure, effective population size, inbreeding and genetic bottlenecks of a population of A. altamirani in a highly disturbed habitat. The study area is subjected to pressures, such as illegal logging introduction of exotic species such as trout, human settlements and pollution of the streams. Under this scenario, we expected that there will be high genetic structure patterns induced by landscape modification and because we studied a small population, isolated and subjected to anthropogenic pressures, this population would present low levels of genetic variability and effective population size, and presence of inbreeding and genetic bottlenecks. This information will help us to raise conservation strategies of this microendemic mole salamander species.

\section{Materials and methods}

\section{Study site and population sampling}

Population samplings were done from January to June 2014 in a small stream $\left( \pm 1 \mathrm{~km}^{2}\right)$ surrounded by induced and alpine grassland near a Pinus hartwegii and Abies religiosa forest and some rural houses in Tlazala, state of México $\left(19^{\circ} 31^{\prime} 31^{\prime \prime} \mathrm{N}, 99^{\circ} 26^{\prime} 09.52^{\prime \prime} \mathrm{W}\right.$ with an altitude of 3185 masl; figure 1). This site is a private land, where ecotourism activities are carried out, along with trout farming, subsistence logging, and cattle and sheep grazing. We obtained 96 tissue samples, the mole salamanders were found in small ponds (transects) of $\sim 40 \mathrm{~cm}$ in depth and $1-2 \mathrm{~m}$ of area separated by $\sim 10-20 \mathrm{~m}$. There were multiple trapping locations along the rivers, so that the sampling areas were chosen for the differences in the microenvironmental characteristics of the river; we found four types of substrates (mud, gravel, bedrock and sand). To represent all maturity stages of $A$. altamirani in the data, tissue was obtained from both adults and larvae. Sampling of larvae was limited $(\geq 10 \%)$ and efforts were made to avoid sampling siblings. The individuals were collected with fishing net and we sampled $2 \mathrm{~mm}^{2}$ of tail clips. This methodology is a low-impact method that does not affect the survival or growth of the mole salamanders (Arntzen et al. 1999; Polich et al. 2013); tissue was preserved in $90 \%$ ethanol and then frozen at $-20^{\circ} \mathrm{C}$ until processed. All mole salamanders were released immediately at the point of capture. Our study received the approval of the ethics committee of Universidad Autónoma del Estado de México (3047-2011E).

\section{DNA extraction and microsatellite amplification}

Genomic DNA was extracted using a commercial kit (Vivantis GF-1 tissue DNA extraction kit); we used nine microsatellite loci (At 52.2, At 52.10, At 52.143, At 60.3, At 52.115, At 52.6, At 52.34, A5 52.20 and At 52.1) specifically developed for Mexican Ambystomas and followed published protocols (Parra-Olea et al. 2007) for amplification. PCR reactions were performed in a Techne thermocycler, amplified products were multiplexed on an ABI Prism3730xl and sized with a ROX-500 as an internal size and then scored using PEAK SCANNER V1.0 (Applied Biosystems, Foster City, USA) software; allele sizes were measured and rounded with the software TANDEM (Matschiner and Salzburger 2009).

\section{Microsatellite analysis}

Potential scoring errors: Typing errors and the presence of null alleles were determined using the Micro-Checker software (Van Oosterhout et al. 2004). 


\section{Revised Proof}

Population genetics of Ambystoma altamirani

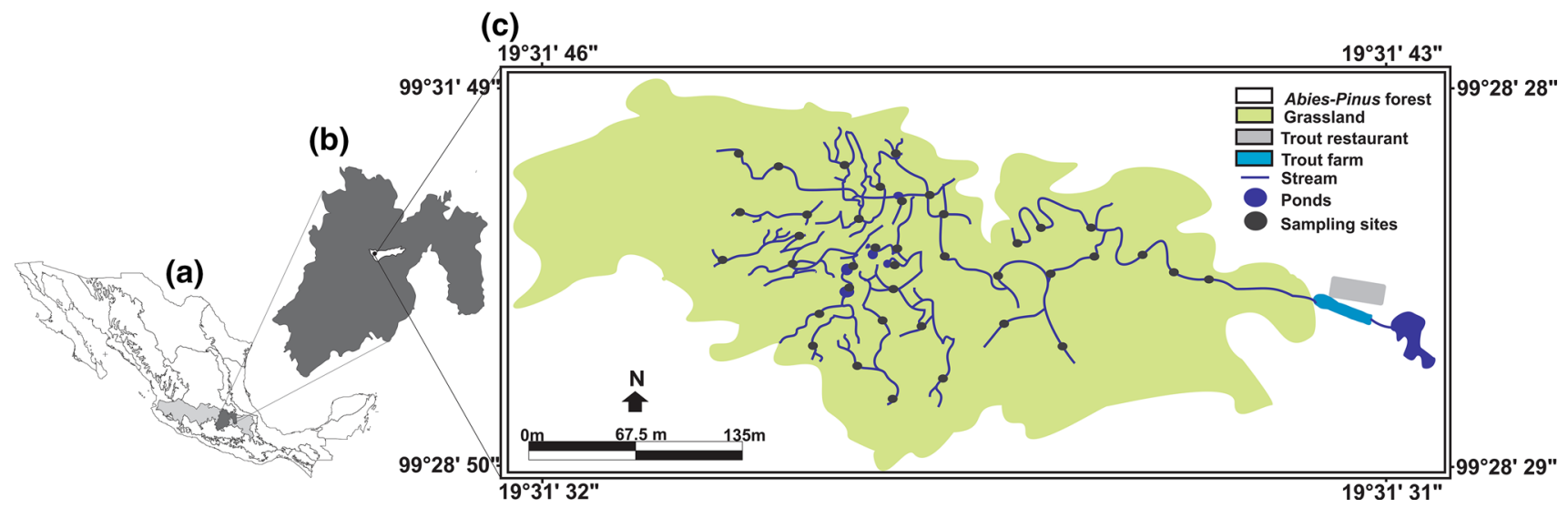

Figure 1. (a) Map of Mexico showing in gray, the TMVB and in dark gray, the State of Mexico. (b) State of Mexico showing in white, Isidro Fabela. (c) The sampling site in Tlazala, Isidro Fabela.

Genetic structure: The Structure 2.3.4 software (Pritchard et al. 2000) was used to infer population structure. First, to determine the degree of admixture, we tested $K=1$ through $K=8$ in 10 independent runs $(10,000$ Markov chains following a burning period of $1,000,000$ ), a Dirichlet parameter was used. The evolution of allele frequencies in each genetic group was correlated with the allele frequencies of an ancestral population, and without prior information on population origin, so the most probable number of clusters which best represent our data was determined following the method in Evanno et al. 2005: the change of $\Delta K$ (i.e., the ad hoc quantity related to the second order rate of change of the log probability of data) with respect to the number of clusters was considered, using the maximum value of $\Delta K$, software Structure Harvester 0.6.92 (Earl and von Holdt 2012) was used.

Genetic variability: Linkage disequilibrium (LD) between all pairs of loci across all populations and Hardy-Weinberg equilibrium (HWE) between loci were determined with Genepop 4.2 (Raymond and Rousset 1995), using an exact test (10,000 dememorization steps, 1000 batches and 10,000 iterations), then, significance of data was analysed with a false discovery rate (FDR) test in R 2.8.1 Q-Value (R Development Core Team 2013).

Genealex was used to estimate the observed number of alleles $\left(N_{\mathrm{a}}\right)$, effective number of alleles per locus, observed heterozygosity $\left(H_{\mathrm{O}}\right)$ and expected heterozygosity $\left(H_{\mathrm{e}}\right)$; also, allelic richness $(A)$ was obtained with FSTAT 2.9.3.2 (Goudet 2001). Additionally, different estimators of genetic population differentiation like: $G_{S T \_e s t}, G_{S T \text { est }}^{\prime}$ (Hedrick 2005; Jost 2008), $\Delta_{S T}, D$ and $D_{\text {est }}$ (Jost 2008) were calculated in the SMOGD 1.2.5 (Crawford 2010) software considering 1000 replicates in the bootstrapped parameters. Finally, Nei's (1972) genetic distance between sampling localities and an analysis of molecular variance (AMOVA) was calculated. Also, Genealex 6.5 (Peakall and Smouse 2006) was used to perform AMOVA to analyse the distribution of the genetic variance between and within populations based on $F_{\mathrm{ST}}$ values, using 999 permutations, were estimated with Genalex 6.5 (Peakall and Smouse 2006).

Gene flow, effective population size, bottlenecks and relatedness: The gene flow was obtained with Genepop 4.2 (Raymond and Rousset 1995) using an exact test (10,000 dememorization steps, 1000 batches and 10,000 iterations) using private alleles method (Barton and Slatkin 1986). Examining LD with software Neestimator 2.01 software (Do et al. 2014), the effective population size $\left(N_{\mathrm{e}}\right)$ was determined. With the software Bottleneck 1.2.02 (Cournet and Luikart 1996; Piry et al. 1999), we tested for population bottleneck events, estimating the observed heterozygosity and expected heterozygosity under the infinite allele model (IAM), stepwise mutation model (SMM) and the two-phase model (TPM), with settings at $90 \%$ SMM, 10\% IAM and 10\% variance and default values (70\% SMM, 30\% IAM and 10\% variance). Both settings were calculated with 10,000 replicates and an excess of heterozygosity was tested with a Wilcoxon test. Finally, historical bottlenecks were also tested; when $M$ values are lower than the critical number, it indicates an historical population declines (Cournet and Luikart 1996; Garza and Williamson 2001). Therefore, we obtained the Garza-Williamson $(M)$ index with Arlequin 3.1.1.2 software (Excoffier et al. 2005) and values of critical $M$ $\left(M_{c}\right)$ were obtained with Critical_M software (Garza and Williamson 2001), using 10,000 simulations and parameters from the two-phase mutation model, as described in Garza and Williamson (2001).

We obtained $F_{\text {IS }}$ value in Genealex as an indicator of total inbreeding in the population and with the same software relatedness estimator of Queller and Goodnight (1989) $\left(r_{q g}\right)$ was obtained to analyse relatedness among populations; significant differences between mean population relatedness were tested using 9999 permutations, which calculates the upper and lower 95\% intervals for 


\section{Revised Proof}

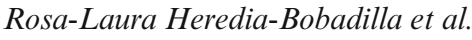

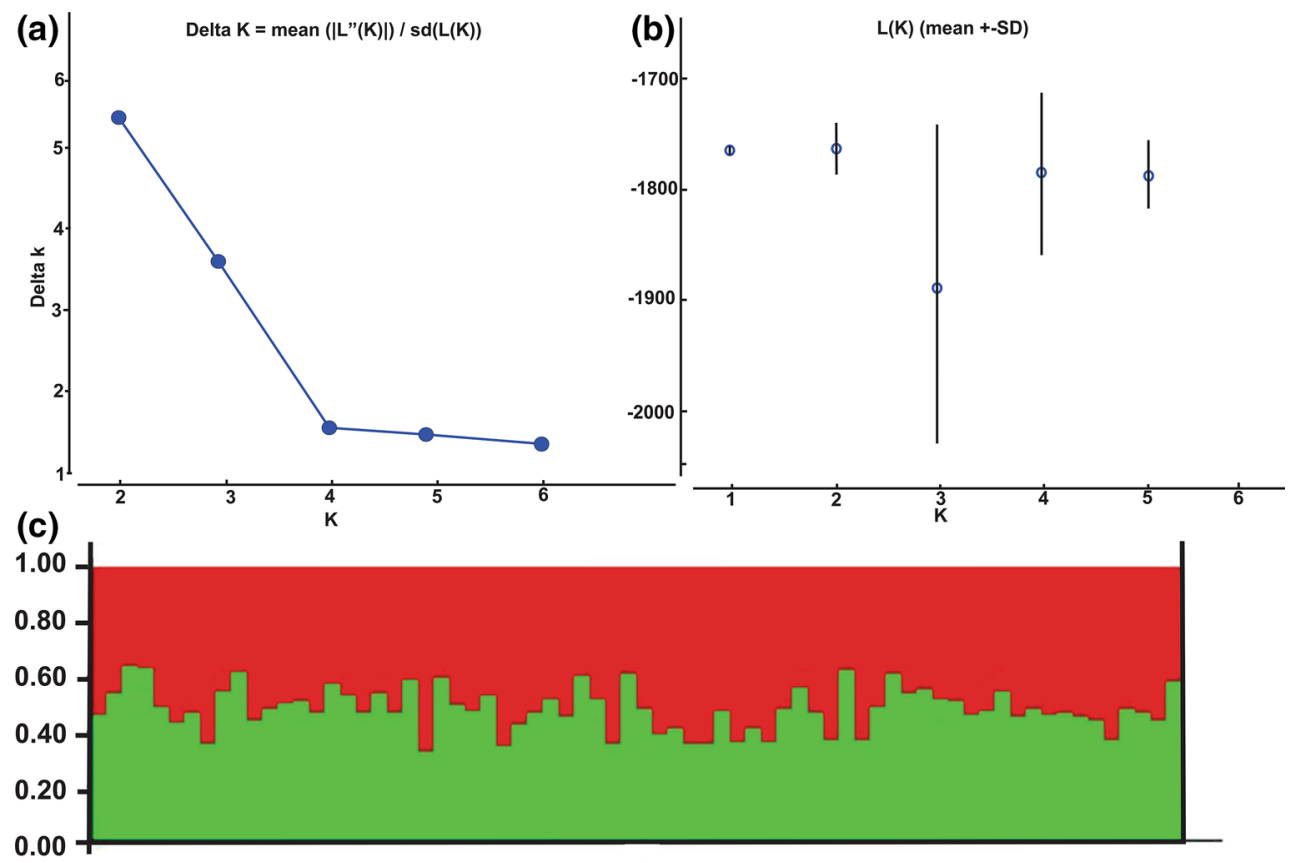

Figure 2. A. altamirani genetic structure: (a) population genetic structure partitioned into $K$ components representing the ancestry fractions in $\ln \operatorname{Pr}(K=2)=-1407.2$ populations. (b and c) $\Delta K$ value of Evanno et al. (2005) plots for detecting the number of $K$ groups that best fit the data.

the expected range of $r_{q g}$ based on the populations. These intervals correspond to the range of $r_{q g}$ that would be expected if reproduction was random across the populations. Also, we estimated confidence intervals to $95 \%$ by bootstrap resampling (9999) within population estimates of mean relatedness. Population $r_{q g}$ values that fall above the $95 \%$ expected values from permutations indicate that processes such as inbreeding or drift are increasing the relatedness.

\section{Results}

\section{Potential scoring errors}

Based on a previous analysis, we decided to eliminate 26 tissues of larvae from the further analysis to avoid unbiased results (genotyping siblings). Finally, null alleles and other typing errors were not detected at any loci.

\section{Genetic structure}

The best log likelihood given by Structure was observed when $K=2(\ln \operatorname{Pr}(K=2)=-1407.2$; figure 2$)$ and $\Delta K$ chose the best model considering two subpopulations (SUBP1: $N=29$, SUBP2: $N=41$ ). Therefore, we performed all analyses considering these two subpopulations. The genetic structure analysis (table 1) showed low genetic structure between subpopulations.

\section{Genetic variability}

FDR correction did not find any departures from HWE at any loci (table 1 in electronic supplementary material at), neither LD was detected at any loci. Across the nine loci in the 70 remaining samples, 34 alleles were identified, with a range of 2-8 (average 3.367) alleles per locus (table 2; figure 1 in electronic supplementary material). In the population, we found 68 genotypes (table 2 in electronic supplementary material); with a range of $2-5$ (average 3.6 ) genotypes per locus for the SUBP1 population and with a range of 3-5 (average of 6.8) for the SUBP2 population. The SUBP1 population had 18 heterozygous genotypes and 15 homozygous genotypes with a total of 33 genotypes, and the SUBP2 had 19 heterozygous genotypes and 16 homozygous genotypes with a total of 35 genotypes (table 2 in electronic supplementary material). The SUBP1 and SUBP2 populations showed lower values expected than observed heterozygosity (table 2). The $F_{\text {ST }}$ AMOVA results revealed that all the genetic variability is attributed to variation within individuals $(100 \% ; P=0.001)$ with an $F_{\text {ST }}$ value of 0.005 (table 3 in electronic supplementary material).

\section{Gene flow, effective population size, bottlenecks and relatedness}

With regard to genetic flow, the number of migrants $\left(N_{\mathrm{m}}\right)$ using private alleles method was 1.74 . The $N_{\mathrm{e}}$ with the LD model and with allelic frequency of 0.05 , was 8.8 for the 


\section{Revised Proof}

Population genetics of Ambystoma altamirani

Table 1. A. altamirani measures of genetic differentiation for the populations and for each locus.

\begin{tabular}{lcccrrrrr}
\hline Loci & $\mathrm{F}_{\mathrm{ST}}$ & $\mathrm{F}_{\mathrm{IT}}$ & $\mathrm{F}_{\mathrm{IS}}$ & $G_{S T \_e s t}$ & $G_{S T \_e s t}^{\prime}$ & $\Delta_{\mathrm{ST}}$ & $D$ & $D_{\text {est }}$ \\
\hline At52.2 & 0.004 & -0.196 & -0.202 & -0.003 & -0.011 & 1.006 & 0.012 & -0.008 \\
At52.10 & 0.000 & -0.258 & -0.258 & -0.007 & -0.054 & 1.000 & 0.000 & -0.046 \\
Atig52.143 & 0.001 & -0.378 & -0.379 & -0.006 & -0.033 & 1.002 & 0.004 & -0.027 \\
At60.3 & 0.007 & -0.743 & -0.756 & 0.000 & 0.000 & 1.007 & 0.015 & 0.000 \\
Atig52.115 & 0.001 & -0.642 & -0.645 & -0.006 & -0.018 & 1.001 & 0.003 & -0.012 \\
At52.6 & 0.015 & -0.372 & -0.394 & 0.008 & 0.039 & 1.030 & 0.058 & 0.031 \\
At52.34 & 0.000 & -0.637 & -0.637 & -0.007 & -0.028 & 1.000 & 0.000 & -0.020 \\
At52.20 & 0.001 & -0.638 & -0.640 & -0.007 & -0.025 & 1.001 & 0.002 & -0.017 \\
At52.1 & 0.013 & -0.134 & -0.149 & 0.006 & 0.065 & 1.065 & 0.123 & 0.059 \\
Mean & 0.005 & -0.444 & -0.451 & -0.002 & -0.007 & 1.012 & 0.024 & -0.004 \\
\hline
\end{tabular}

$F_{\mathrm{IS}}, F_{\mathrm{ST}}$ and $F_{\mathrm{IT}}$ fixation indices estimated according to (Weir and Cockerham 1984). $G_{S T}$ est , nearly unbiased estimator of relative differentiation (Nei 1983); $G_{S T \text { est }}^{\prime}$, standardized measure of genetic differentiation (Hedrick 2005); $\Delta_{\mathrm{ST}}$, between subpopulation component of diversity or the effective number of distinct subpopulations. $D$, actual differentiation; $D_{\text {est }}$, estimator of actual differentiation (Jost 2008).

Table 2. A. altamirani genetic diversity values in SUBP1 and SUBP2 populations.

\begin{tabular}{llllllll}
\hline & $H_{\mathrm{o}}$ & $H_{\mathrm{e}}$ & $N$ & $N_{\mathrm{a}}$ & $N_{\mathrm{e}}$ & $N_{\mathrm{p}}$ & $F_{\mathrm{IS}}$ \\
\hline SUBP1 & 0.870 & 0.621 & 29 & 3.556 & 2.864 & 0 & -0.423 \\
SUBP2 & 0.897 & 0.621 & 41 & 3.778 & 3.052 & 2 & -0.479 \\
Mean & 0.883 & 0.621 & 35 & 3.667 & 2.958 & 0.500 & -0.444 \\
\hline
\end{tabular}

$N$, sample size; $N_{\mathrm{a}}$, number of alleles; $N_{\mathrm{e}}$, number of effective alleles; $N_{\mathrm{p}}$, number of private alleles; $H_{\mathrm{o}}$, observed heterozygosity; $H_{\mathrm{e}}$, expected heterozygosity; $F_{\mathrm{IS}}$, fixation index.

whole population and for subpopulations: SUBP1, $N_{\mathrm{e}}=$ 5.6 and $\mathrm{SUBP} 2, N_{\mathrm{e}}=7.2$.

The Bottleneck analysis detected genetic signs of recent demographic changes typical of bottleneck events, associated with a heterozygote excess at the two subpopulations under the IAM, SMM and TPM models (SUBP1: $P=$ $0.00001,0.0080,0.00205$; SUBP2: $P=0.00001,0.00067$, 0.00192 ; table 4 in electronic supplementary material).
Critical $M_{c}$ values were significantly higher (SUBP1: $M_{c}=$ 0.9, SUBP2: $M_{c}=0.8$ ) than $M$ values (SUBP1: $M=0.486$, SUBP2: $M=0.474$ ) in the two subpopulations, indicating historical reductions in effective population size or historical bottlenecks. The $F_{\text {IT }}$ statistic as an indicator of inbreeding for the whole population showed negative and high inbreeding values $\left(F_{\mathrm{IT}}=-0.444\right.$; table 1$)$. We found that mean pairwise relatedness $(r)$ within populations (figure 3 ) was generally in accordance with that observed in other Ambystoma populations (Parra-Olea et al. 2012; Sunny et al. 2014a; Percino-Daniel et al. 2016). SUBP1 had low values of inbreeding (mean $r_{q g}=-0.036$, confidence inter$\operatorname{val}(\mathrm{CI})=0.052-(-0.051))$, while SUBP2 had highest value of inbreeding (mean $r_{q g}=0.018, \mathrm{CI}=0.034-(-0.037)$ ).

\section{Discussion}

The limited distribution and anthropogenic activities such as river pollution, deforestation and introduction of exotic species like trout, increase the possibility of $A$. altamirani

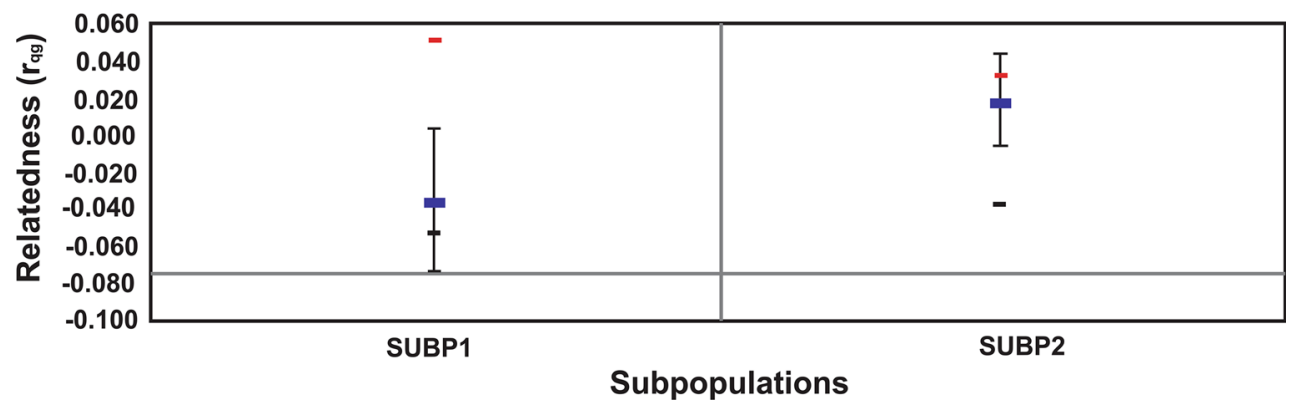

Figure 3. Mean within-populations pairwise relatedness coefficient, $r_{q g}$ across the $A$. altamirani populations studied. The red bars are $95 \%$ upper expected values and the black bars are $95 \%$ lower expected values for a null distribution generated from 999 permutations of data from all populations, and enclose the values expected if breeding were panmictic across the populations. Blue bars represent the observed mean relatedness in each population, with the upper and lower bootstrap values for each subpopulation. 


\section{Revised Proof}

Rosa-Laura Heredia-Bobadilla et al.

populations to became endanger (Funk and Dunlap 1999; Shaffer et al. 2008). In the present study, we found high levels of genetic variability and different genetic groups as Structure suggest that the genetic structure captured appears to be an isolation by distance effect, while a large amount of admixture is occurring along this stream, but there is also signs of low effective population size and genetic bottlenecks. These results are important in terms of the conservation genetics perspective, because the high levels of genetic variability found, can be declining due to the bottlenecks and the low levels of effective population size.

\section{Genetic structure}

The structure analysis found two subpopulations (SUBP1 and SUBP2; figure 2, table 2) with very low genetic differentiation among them $\left(F_{\mathrm{ST}}=0.005\right)$. The low genetic structure found could be due to an isolation by distance effect (IBD), with a large amount of admixture, these subpopulations are making a metapopulation system rather than isolated populations, the metapopulation pattern is common in amphibians (Rowe et al. 2000; Newman and Squire 2001; Palo et al. 2003; Funk et al. 2005; Jehle et al. 2005; Spear et al. 2005; Johansson et al. 2006; Giordano et al. 2007; Noël et al. 2007; Zamudio and Wieczorek 2007; Purrenhage et al. 2009; Consentino et al. 2012; Sunny et al. 2014a, b; Monroy-Vilchis et al. 2015). On the other hand, probably, the subpopulations could be starting an isolation process and this is reflected in our Structure test, there are physical factors that could isolate small groups and make them genetically different, changes in the stream like the closeness with the trout area, changes in water speed, oxygenation and depth; even substrate types are pointed out as factors that have repercussions in genetic structure of Ambystomas (Sunny et al. 2014b; Lemos-Espinal et al. 2016). A. altamirani prefers stream sites with certain peculiarities like places with a greater volume of water, higher dissolved oxygen levels, faster moving water, sites with emergent grass and forbs, and sites with black-coloured substrates like mud and sand (Sunny et al. 2014b; LemosEspinal et al. 2016); it avoids sites with no vegetation and those with gravel or bedrock bottoms in which it is easier to be observed, making it more exposed to predation. In the study site, mud and sand substrates are usually separated for every $10-20 \mathrm{~m}$ and this in fact congregate the individuals in ponds (separated 10-20 m), this may be causing isolation of small groups, which in our study are represented by SUBP1 and SUBP2, structuring the population and favouring the metapopulation pattern.

\section{Genetic variability}

The observed heterozygosity values were high and most of thegenotypes were heterozygous (table 2; table 2 in electronic supplementary material); high levels of genetic variability are not unusual in Ambystoma species (Goprenko et al. 2007; Greenwald et al. 2009; Sunny et al. 2014a; Heredia-Bobadilla et al. 2016; Percino-Daniel et al. 2016), despite with a limited distribution. The genetic variability found in this study was higher than that reported for A. altamirani from the Lagunas de Zempoala National Park (LZNP) (Parra-Olea et al. 2012), this may be due to the high anthropogenic pressures occurring in the LZNP, of the seven lagoons that inhabited A. altamirani, three are already completely dried and in the four other lagoons, the aquatic vegetation is disappearing and pollution is increasing and the deforestation and ecotourism activities are devastating the ecosystem (Islebe et al. 2003; LemosEspinal 2003; Parra-Olea et al. 2012). In the studied area, human activities are carried out, such as subsistence logging, cows and sheep grazing, ecotourism activities and recreational trout fishing, but because this area is not a touristic site, all these activities are on a small scale, which may be helped to preserve the genetic variability set-up in the habitat. Besides this, some Ambystoma characteristics could favour the high genetic variability set-up, like the high rates of breeding, multiple paternity and overlapping generations; also, it is reported that one $A$. altamirani female clutch can contain up to 10 or 21 eggs and can be larger, three years after the first clutch (Rodríguez-Reyes 2009), also the migration of one female can contribute to an increase in the genetic variability of the population (Tennessen and Zamudio 2003; Kinkead et al. 2006; Rodríguez-Reyes 2009; Iwao 2012; Lemos-Espinal et al. 2016). Unfortunately, we also found very low average numbers of alleles compared with other northern Ambystoma species like A. tigrinum, A. maculatum and A. macrodactulym (range $N_{\mathrm{a}}=3.5-12.0$; Giordano et al. 2007; Zamudio and Wieczorek 2007; Purrenhage et al. 2009) and lower than some Mexican Ambystoma species (A. leorae, A. rivulare, $A$. velasci; range $N_{\mathrm{a}}=4.0-6.0$ per locus; Parra-Olea et al. 2012; Sunny et al. 2014a), but similar values to the A. altamirani population of LZNP $\left(N_{\mathrm{a}}=3.5\right.$; Parra-Olea et al. 2012). However, these results should be interpreted with caution because the number of alleles is a relative value as it depends on the number and type of loci studied, number of individuals and the population characteristics (Vázquez-Domínguez et al. 2013; Sunny et al. 2015). However, it is possible that the low number of alleles found in the clusters is a sign that genetic variability and allelic richness are declining as a result of habitat fragmentation and anthropogenic activities, which are leading to population declines and isolation which in turn could cause genetic drift (Rueda-Zozaya et al. 2016). The observed high heterozygosity values could be signs of retention of ancestral polymorphisms or standing genetic variation, which is pre-existing in the population (Kinkead et al. 2006; Weisrock et al. 2006; Recuero et al. 2010; Hedrick 2011). 


\section{Revised Proof}

Population genetics of Ambystoma altamirani

\section{Gene flow, effective population size, bottlenecks and relatednesss}

The study population is isolated from other populations of $A$. altamirani, because the stream has no connection to other tributaries or rivers, consequently, gene flow only occurs between the pools that are within this river. We found low, but significant levels of gene flow $\left(N_{\mathrm{m}}=1.74\right.$ means that in five generations, there are $\approx 8-9$ migrants), this also explains the low genetic differentiation $\left(F_{\mathrm{ST}}=\right.$ 0.005). There are some characteristics of the biology of the mole salamander that favours the low gene flow and also the genetic structure, like the philopatric tendencies and low vagility (Funk et al. 2005; Savage and Zamudio 2005; Spear et al. 2005; Gamble et al. 2007; Vences and Wake 2007; Calhoun and deMaynadier 2008; Semlitsch 2008; Wang et al. 2009; Wang and Summers 2010; Parra-Olea et al. 2012; Sunny et al. 2014a; Sunny et al. 2014b; HerediaBobadilla et al. 2016; Percino-Daniel et al. 2016). During the six months of sampling, we found the same individuals in the same pond, which reflects few migratory movements; although, this species can undergo metamorphosis, A. altamirani prefers to stay in the water (Lemos-Espinal et al. 1999; Shaffer et al. 2008), thus, it is unlikely that A. altamirani can be dispersed by land in this locality. Outside the stream, there are grasslands where human activities such as subsistence logging, cows and sheep grazing, ecotourism activities and recreational trout fishing are held, and occasionally, there are feral dogs and cats. All these features have made unfavourable microclimatic conditions necessary for A. altamirani to migrate. To make the mole salamanders to migrate, it is necessary to have forest coverage with enough vegetation and moisture; when these characteristics are not present, mole salamanders can be predated or die by desiccation (Naughton et al. 2000; Rhotermel and Luhring 2005; Spear et al. 2005; Cushman 2006; Noël and Lapointe 2010; Becker et al. 2016). Likewise, migration patterns occur mainly between neighbouring populations, which may suggest a stepping stone pattern and a metapopulation behaviour; the few migrants pattern also is a common trend in mole salamander populations and mainly in high mountain populations (Marsh and Trenham 2001; Kinkead et al. 2006; Savage et al. 2010; Parra-Olea et al. 2012; Sunny et al. 2014a).

The population size that is relevant for evolutionary matter is the number of breeding individuals; the effective population size of $A$. altamirani was very low, the low $N_{\mathrm{e}}$ values can be caused by genetic isolation, asymmetry in the proportion of males and females and differences in the reproductive success between individuals (Tennessen and Zamudio 2003; Wang et al. 2009; Hedrick 2011), generally, the mole salamanders have low $N_{\mathrm{e}}$ values (Wang et al. 2009; Savage et al. 2010; Parra-Olea et al. 2012; Sunny et al. 2014a; Percino-Daniel et al. 2016) due to high asymmetry in reproductive success among members of a population (Savage et al. 2010). If only a few individuals successfully breed one year, the variance in mating success may contribute strongly to low overall effective population sizes (Brandon and Altig 1973; Savage et al. 2010). The low $N_{\mathrm{e}}$ could also be explained by a bottleneck effect; and the bottlenecks found in our study can be explained because trout was recently introduced in the sampled stream for recreational fishing and now the mole salamanders compete with trout for food (Werner and Anholt 1996; Tyler et al. 1998), and are being predated upon in the early stages of development (Matthews et al. 2001; Pilliod and Peterson 2001; Welsh et al. 2006; Zambrano et al. 2010; MartínTorrijos et al. 2016) and transfer of pathogens and some emerging infectious diseases (Blaustein et al. 2005; Johnson and Speare 2005; Fernández-Benéitez et al. 2008; Van den Berg et al. 2013; Sandoval-Sierra et al. 2014) causing embryonic mortality and several amphibian declines (Fernández-Benéitez et al. 2008), and also the A. altamirani individuals find it very difficult to recognize trout as a predator, because they do not have an evolutionary predator-prey history (Petranka et al. 1987; Funk and Dunlap 1999; Pilliod and Peterson 2001; Pearson 2004; Gall and Mathis 2010; Zambrano et al. 2010). All these features can lead the population to a process of genetic drift which in turn reduces genetic variability, making the population to lose fitness and the possibility to adapt to changes in the environment (Frankham et al. 2005). Some studies concluded that a minimum of one migrant per generation is sufficient to avoid consanguinity effects, but in small and fluctuating populations, 3-10 migrants per generation are necessary to maintain a particular level of inbreeding (Vucetich and Waite 2000). We found low to medium levels of inbreeding in our analyses, the $r_{q g}$ values in the two subpopulations were above the $95 \%$ expected values from permutations, indicating that inbreeding or drift could be increasing relatedness, the $r_{q g}$ values were lower than those found in the LZPN A. altamirani population, the $r_{q g}$ values were higher $\left(r_{q g}=0.620\right.$; Parra-Olea et al. 2012), suggesting that in disturbed habitats the inbreeding increases.

\section{Conservation implications}

A. altamirani population studied are threatened by habitat fragmentation, deforestation, pollution of streams and introduction of trout. These are important to consider since amphibians are particularly sensitive to local habitat alterations (Castellano and Valone 2006; Ribeiro et al. 2009), because of their ecological low dispersal capacity and small home ranges (Huey 1982). The population studied has high heterozygosity values, alleles and genotypes, which are necessary to preserve, so that the species could have enough genetic variability and can adapt to changes in the environment. It is necessary to conserve unique genes, which could be essential for genetic rescue programmes of this mole salamander (Petit et al. 1996; Frankham et al. 2002). The population also has signs of inbreeding signs and reduced effective population size 
caused probably by bottlenecks, this is important to consider because this phenomena could increase the genetic drift which in turn will cause a decline in the heterozygosity levels found and a decrease in the genetic variability found. Also, it is important to conserve the endangered Abies-Pinus habitat and the streams in this habitat to maintain the A. altamirani populations and other species of amphibians and reptiles that live in this type of habitat. Therefore, we propose to increase the natural protected areas because this strategy has been an effective way to protect biodiversity (Ledig 1988). In the study area, conifer woods are declining because of illegal and subsistence logging, as a measure to avoid this problem, the authorities are making reforestations, but this measure is not adequate since they are reforesting the Abies forests with other species such as: Pinus pseudostrobus, Pinus patula and Pinus hartwegii, this forest management plan changes the microclimate, environmental and habitat conditions necessary to this species and others to persist. Also, we propose to implement environmental education, not only to local communities, but also to the authorities to avoid bad forest management practices. As well, it is necessary to implement solar technologies in the communities, such as solar water heaters and solar stoves since the majority of the logging of the communities is to be able to heat the water and to cook. In addition, more studies are needed to create a complete genetic conservation programme of this Ambystoma species, but the genetic information provided in this study can be used as a first attempt and the basis for future research and conservation planning in A. altamirani.

\section{Acknowledgements}

We are deeply grateful to the students of CICBA for helping us in data collection and laboratory assistance. We thank the editor and two anonymous reviewers for their comments. RLHB is grateful to the graduate programme 'Doctorado en Ciencias Agropecuarias y Recursos Naturales' of the Autonomous University of the State of Mexico and for scholarships received from CONACYT and COMECYT (359990 and 16BTID0028). This work was funded by Autonomous University of the State of Mexico (3047-2011E).

\section{References}

Allentof M. E. and O’Brien J. 2010 Global amphibian declines, loss of genetic diversity and fitness: a review. Diversity 2, 47-71.

Anadón J. D., Gimenez A., Martínez M., Martínez J., Perez I. and Esteve M. A. 2006 Factors determining the distribution of the spur-thighed tortoise Testudo graeca in south-east Spain: a hierarchical approach. Ecography 29, 339-346.

Arntzen J. W., Smithson A. and Oldham R. S. 1999 Marking and tissue sampling effects on body condition and survival in the newt Triturus cristatus. J. Herpetol. 33, 567-576.

Barton N. H. and Slatkin M. 1986 A quasi-equilibrium theory of the distribution of rare alleles in a subdivided population. Heredity 56, 409-415.
Becker C. G., Logo A. V., Toledo F. L., Lambertini C., Leite D. S., Haddad C. F. B. and Zamudio K. R. 2016 Deforestation, host community structure and amphibian disease risk. Basic Appl. Ecol. 17, 72-80.

Beebee T. J. and Griffiths R. A. 2005 The amphibian decline crisis: a watershed for conservation biology? Biol. Conserv. 125, 271285.

Blaustein A. R., Romansic J. M., Scheessele E. A., Han B. A., Pessier A. P. and Longcore J. E. 2005 Interspecific variation in susceptibility of frog tadpoles to the pathogenic fungus Batrachochytrium dendrobatidis. Conserv. Biol. 19, 1460-1468.

Brandon R. A. and Altig R. G. 1973 Eggs and small larvae of two species of Rhyacosiredon. Herpetologica 29, 349-351.

Calhoun A. J. K. and deMaynadier P. G. 2008 Science and conservation of vernal pools in northeastern North America. CRC Press, Boca Raton, UK.

Casas-Andreu G., Cruz-Aviña R. and Aguilar-Miguel X. 2004 Un regalo poco conocido de México al mundo: el ajolote o axolotl (Ambystoma: Caudata: Amphibia) Con algunas notas sobre la crítica situación de sus poblaciones. Ciencia ergosum10, 304-308.

Castellano M. J. and Valone T. J. 2006 Effects of livestock removal and perennial grass recovery on the lizards of a desertified arid grassland. J. Arid Environ. 66, 87-95.

Consentino B. J., Phillips C. A., Chooley R. L., Lowe H. W. and Douglas M. R. 2012 Linking extinction-colonization dynamics to genetic structure in a salamander metapopulation. Proc. R. Soc. Ser. London, B279, 1575-1582.

Contreras V. E., Martínez-Meyer E., Valiente E. and Zambrano L. 2009 Recent decline and potential distribution in the last remnant area of the microendemic Mexican axolotl (Ambystoma mexicanum). Biol. Conserv. 142, 2881-2885.

Cournet J. M. and Luikart G. 1996 Description and power analysis of two tests for detecting recent populations bottleneck from allele frequency data. Genetics 144, 2001-2014.

Crawford N. G. 2010 SMOGD: software for the measurement of genetic diversity. Mol. Ecol. Resour. 10, 556-557.

Cushman S. A. 2006 Effects of habitat loss and fragmentation on amphibians: a review and prospectus. Biol. Conserv. 128, 231-240.

Do C., Waples R. S., Peel D., Macbeth G. M., Tillett B. J. and Ovenden J. R. 2014 NeEstimator V2: re-implementation of programa for the estimation of contemporary effective population size $(\mathrm{Ne})$ from genetic data. Mol. Ecol. Resour. 14, 209-214.

Earl D. A. and von Holdt B. M. 2012 Structure Harvester: a website and program for visualizing Structure output and implementing the Evanno method. Conserv. Genet. Resour. 4, 359-361.

Ellis E. A. and Porter-Bolland L. 2008 Is community-based forest management more effective than protected areas?: A comparison of land use/land cover change in two neighboring study areas of the Central Yucatan Peninsula, Mexico. Forest Ecol. Manag. 256, 1971-1983.

Evanno G., Regnaut S. and Goudet J. 2005 Detecting the number of clusters of individuals using the software STRUCTURE: a simulation study. Mol. Ecol. 14, 2611-2620.

Excoffier L., Laval G. and Schneider S. 2005 ARLEQUIN ver. 3.0: an integrated software package for population genetics data analysis. Evol. Bioinform. Online 1, 47-50.

FAO 2006 FAO Statistics database (http://faostat.fao.org/. Accessed 10 June 2016).

Farías-Álvarez P., Zúniga-Vega J. J. and Flores-Villela O. 2010 A general assessment of the conservation status and decline trends of Mexican amphibians. Biodivers. Conserv. 19, 3699 3742 . 


\section{Revised Proof}

Population genetics of Ambystoma altamirani

Fernández-Benéitez M. J., Ortiz-Santaliestra M. E., Lizana M. and Diéguez-Uribeondo J. 2008 Saprolegnia diclina: another species responsible for the emergent disease 'Saprolegnia infections' in amphibians. FEMS Microbiol. Lett. 279, 23-29.

Frankham R., Ballou J. D. and Briscoe D. A. 2002 Introduction to conservation genetics. Cambridge University Press, Cambridge, UK.

Frankham R., Ballou J. and Briscoe D. 2005 Introduction to conservation genetics. Cambridge University Press, Cambridge.

Frías-Álvarez P., Vredenburg V. T., Familiar-López M., Longcore J. E., González-Bernal E., Santos-Barrera G. et al. 2008 Chytridiomycosis survey in wild and captive Mexican amphibians. EcoHealth 5, 18-26.

Funk W. C. and Dunlap W. W. 1999 Colonization of high elevation lakes by long-toed salamanders (Ambystoma macrodactylum) after the extinction of introduced trout populations. Can. J. Zoolog. 77, 1759-1767.

Funk W. C., Blouin M. S., Corn P. S., Maxell B. A., Pilliod D. S., Amish S. and Allendorf F. W. 2005 Population structure of Columbia spotted frogs (Rana luteiventris) is strongly affected by the landscape. Mol. Ecol. 14, 483-496.

Gall B. G. and Mathis A. 2010 Innate predator recognition and the problem of introduced trout. Ethology 116, 47-58.

Gamble L. R., McGarigal K. and Compton B. W. 2007 Fidelity and dispersal in the pond-breeding amphibian, Ambystoma opacum: implications for spatio-temporal population dynamics and conservation. Biol. Conserv. 139, 247-257.

Garza J. C. and Williamson E. G. 2001 Detection of reduction in population size using data from microsatellite loci. Mol. Ecol. 10, 305-318.

Giordano A. R., Ridenhour B. J. and Storfer A. 2007 The influence of altitude and topography on genetic structure in the long-toed salamander (Ambystoma macrodactulym). Mol. Ecol. 16, 1625-1637.

Goprenko D., Williams R. N. and DeWoody J. A. 2007 Reproductive and mating success in the small-mouthed salamander (Ambystoma texanum) estimated via microsatellite parentage analysis. Evol. Biol. 34, 130-139.

Goudet J. 2001 FSTAT, a program to estimate and test gene diversities and fixation indices, ver. 2.9 .3 (http://www.citeulike.org/ user/argosmarulanda/article/7617994).

Greenwald K. R., Gibbs H. L. and Waite A. T. 2009 Efficacy of land-cover models in predicting isolation of marbled salamander populations in a fragmented landscape. Conserv. Biol. 25, 1232-1241.

Griffiths R. A., Graue V., Bride I. G. and McKay J. E. 2004 Conservation of the axolotl (Ambystoma mexicanum) at Lake Xochimilco, Mexico. Herpetol. Bull. 89, 4-11.

Hedrick P. 2005 Genetics of populations. Jones and Bartlett, Sudbury, Canada.

Hedrick P. W. 2011 Genetics of populations, 4th edition. Jones and Bartlett Publishers, USA.

Heredia-Bobadilla R. L., Monroy-Vilchis O., Zarco-González M. M., Martínez-Gómez D., Mendoza-Martínez G. D. and Sunny A. 2016 Genetic structure and diversity in an isolated population of an endemic mole salamander (Ambystoma rivulare Taylor, 1940) of central Mexico. Genetica 144, 689-698.

Huey R. B. 1982 Temperature, physiology, and the ecology of reptiles. In Biology of the reptilia. Physiology C-Physiological Ecology (ed. C. Gans and F. H. Pough), pp. 25-91. Academic Press, New York, USA.

Islebe G., Almeida-Leñero L., Cleef A. M. and Weijden R. 2003 Fitosociología y fitodiversidad de la laguna Quila Parque
Nacional Lagunas de Zempoala, México. Acta. Bot. Mex. 65, 61-82.

Iwao Y. 2012 Egg activation in physiological polyspermy. Reproduction 144, 11-22.

Jäggi C. and Baur B. 1999 Overgrowing forest as a possible cause for the local extinction of Vipera aspis in the northern Swiss Jura Mountains. Amphibia-Reptilia 20, 25-34.

Jehle R., Wilson G. A., Arntzen J. W. and Burke T. 2005 Contemporary gene flow and the spatio-temporal genetic structure of subdivided newt populations (Triturus cristatus, T. marmoratusi). J. Evol. Biol. 18, 619-628.

Johansson M., Primmer C. R. and Merila J. 2006 History vs. current demography: explaining the genetic population structure of the common frog (Rana temporaria). Mol. Ecol. 15, 975-983.

Johnson M. L. and Speare R. 2005 Possible modes of dissemination of the amphibian chytrid Batrachochytrium dendrobatidis in the environment. Dis. Aquat. Org. 65, 181-186.

Jost L. 2008 G(ST) and its relatives do not measure differentiation. Mol. Ecol. 17, 4015-4026.

Kim I., Phillips J., Monjeau J., Birney E., Noack K., Pumo D. et al. 1998 Habitat islands genetic diversity and gene flow in a Patagonian rodent. Mol. Ecol. 7, 667-678.

Kinkead K. E., Abbott A. G. and Otis D. L. 2006 Genetic variation among Ambystoma breeding populations on the Savannah River Site. Conserv. Genet. 8, 281-292.

Lande R. 1998 Genetics and demography in biological conservation. Science 241, 1455-1460.

Ledig F. T. 1988 The conservation of diversity in forest trees, why and how should genes be conserved? BioScience 38, 471-479.

Lemos-Espinal J. A. 2003 Rhyacosiredon altamirani. Fichas diagnósticas para 10 especies de anfibios y reptiles Mexicana. Facultad de Estudios Superiores Iztacala, Universidad Nacional Autónoma de México. Bases de datos SNIB-CONABIO, Proyecto W002, México.

Lemos-Espinal J. A., Smith G. R., Ballinger R. E. and RamirezBautista A. 1999 Status of protected endemic salamanders (Ambystoma: Ambystomatidae: Caudata) in the Transvolcanic Belt of México. Herpetol. Bull. 68, 1-4.

Lemos-Espinal J. A., Smith G. R., Hernández Ruiz A. and Montoya Ayala R. 2016 Stream use and population characteristics of the endangered salamander, Ambystoma altamirani from the Arroyo Los Axolotes, State of México, México. Southwestern Nat. 61, 28-32.

Marsh D. M. and Trenham P. C. 2001 Metapopulation dynamics and amphibian conservation. Conserv. Biol. 15, 40-49.

Martín-Torrijos L., Sandoval-Sierra J. V., Muñoz J., DiéguezUribeondo J., Bosch J. and Guayasamin J. M. 2016 Rainbow trout (Oncorhynchus mykiss) threaten Andean amphibians. Neotrop. Biodivers. 2, 26-36.

Matschiner M. and Salzburger W. 2009 Tándem: integrating automated allele binning into genetics and genomics workflows. Bioinformatics 25, 1982-1983.

Matthews K. R., Pope K. L., Preisler H. K. and Knapp R. A. 2001 Effects of nonative trout on Pacific treefrogs (Hyla regilla) in the Sierra Nevada. Copeia2001, 1130-1137.

Monroy-Vilchis O., Zarco-González M. M., Domínguez-Vega H. and Sunny A. 2015 Ambystoma leorae (Taylor, 1943). New records, natural history notes and threat status. Herpetozoa 27 , 166-168.

Naughton G. P., Henderson C. B., Foresman K. R. and McGraw R. L. 2000 Long-toed salamanders in harvested and intact Douglas-fir forests of western Montana. Ecol. Appl. 10, 16811689.

Nei M. 1972 Genetic distance between populations. Am. Nat. 106, 283-292. 
Newman D. and Tallmon D. A. 2001 Experimental evidence for beneficial fitness effects of gene flow in recently isolated populations. Conserv. Biol. 15, 1054-1063.

Newman R. A. and Squire T. 2001 Microsatellite variation and fine-scale population structure in the wood frog (Rana sylvatica). Mol. Ecol. 10, 1087-1100.

Noël S. and Lapointe F. J. 2010 Urban conservation genetics: study of a terrestrial salamander in the city. Biol. Conserv. 143, 2823-2831.

Noël S., Ouellet M., Galois P. and Lapointe F. J. 2007 Impact of urban fragmentation on the genetic structure of the eastern red-backed salamander. Conserv. Genet. 8, 599-606.

Nori J., Lemes P., Urbina-Cardona N., Baldo D., Lescano J. and Loyola R. 2015 Amphibian conservation, land use changes and protected areas: a global overview. Biol. Cons. 191, 367-374.

Palo J. U., O'Hara R. B. and Laugen A. R. 2003 Latitudinal divergence on common frog (Rana temporaria) life history traits by natural selection evidence from a comparison of molecular and quantitative genetic data. Mol. Ecol. 12, 1963-1978.

Parra-Olea G., Recuero E. and Zamudio K. R. 2007 Primer note: polymorphic microsatellite markers for Mexican salamanders of the genus. Mol. Ecol. Notes. 7, 818-820.

Parra-Olea G., Zamudio K. R., Recuero E., Aguilar-Miguel X., Huacuz D. and Zambrano L. 2012 Conservation genetics of threatened Mexican axolotls (Ambystoma). Anim. Conserv. 15, 61-72.

Peakall R. and Smouse P. E. 2006 GENALEX 6: genetic analysis in Excel Population genetic software for teaching and research. Mol. Ecol. Notes 6, 288-295.

Pearson K. J. 2004 The effects of introduced fish on the long-toed salamander (Ambystoma macrodactylum) in southwestern Alberta, Canada. B.Sc. thesis, University of Alberta, Canada.

Percino-Daniel R., Recuero E., Vázquez-Domínguez E., Zamudio K. R. and Parra-Olea G. 2016 All grown-up and nowhere to go: paedomorphosis and local adaptation in Ambystoma salamanders in the Cuenca Oriental of México. Biol. J. Linn. Soc. 118, 582-597.

Petit R. J., Abdelhamid E. M. and Pons O. 1996 Identifiying populations for conservation on the basis of genetic markers. Conserv. Biol. 12, 844-855.

Petranka J. W., Kats L. B. and Sih A. 1987 Predator-prey interactions among fish and larval amphibians: use of chemical cues to detect predatory fish. Anim. Behav. 35, 420-425.

Pilliod D. S. and Peterson C. R. 2001 Local and landscape effects of introduced trout on amphibians in historically fishless watersheds. Ecosystems 4, 322-333.

Piry S., Luikart G. and Cornuet J. M. 1999 BOTTLENECK: a computer program for detecting recent reductions in the effective population size using allele frequency data. J. Hered. 90, 502-503.

Polich R. L., Searcy C. A. and Shaffer H. E. 2013 Effects of tail clipping on survivorship and growth of larval salamanders. $J$. Wildl. Manag. 77, 1420-1425.

Pritchard J. K., Stephens M. and Donnelly P. 2000 Inference of population structure using multilocus genotype data. Genetics 155, 945-959.

Purrenhage J. L., Niewiarowski P. H. and Moore F. B. G. 2009 Population structure of spotted salamanders (Ambystoma maculatum) in a fragmented landscape. Mol. Ecol. 18, 235247.

Queller D. C. and Goodnight K. 1989 Estimating relatedness using genetic markers. Evolution 43, 258-275.

R Development Core Team $2013 \mathrm{R}$ : A language and environment for statistical computing. R Foundation for Statistical Computing, Vienna, Austria. Accessed 15 October 2015 (http:// www.r-project.org).
Raymond M. and Rousset F. 1995 GENEPOP v 12: population genetics software for exact test and ecumenicism. J. Hered. 86, 248-249.

Recuero E., Cruzado-Cortes J., Parra-Olea G. and Zamudio K. R. 2010 Urban aquatic habitats and conservation of highly endangered species: the case of Ambystoma mexicanum (Caudata, Ambystomatidae). Ann. Zool. Fenn. 47, 223-238.

Rhotermel B. B. and Luhring T. M. 2005 Burrow availability and dessication risk of mole salamanders (Ambystoma tailpoideum) in harvested versus unharvested forests stands. J. Herpetol. 39, 619-626.

Ribeiro R., Santos X., Sillero N., Carretero M. A. and Llorente G. A. 2009 Biodiversity and land uses at a regional scale: is agriculture the biggest threat for reptile assemblages? Acta. Oecol. 35, 327-334.

Rodríguez-Reyes F. R. 2009 Dinámica poblacional del ajolote Ambystoma altamirani en el río magdalena, Distrito Federal. B.Sc. thesis, Facultad de Ciencias, UNAM, México. Accessed 25 April 2013 (bibliotecacentral.unam.mx).

Rowe G., Beebee T. J. C. and Burke T. 2000 A microsatellite analysis of natterjack toad Bufo calamita metapopulations. Oikos 88, 641-651.

Rueda-Zozaya P., Mendoza-Martínez G. D., Martínez-Gómez D., Monroy-Vilchis O., Godoy J. A., Sunny A. et al. 2016 Genetic variability and structure of jaguar (Panthera onca) in Mexican zoos. Genetica 144, 59-69.

Sandoval-Sierra J. V., Martín M. P. and Diéguez-Uribeondo J. 2014 Species identification in the genus Saprolegnia (Oomycetes): defining DNA-based molecular operational taxonomic units. Fungal Biol. 118, 559-578.

Savage W. K. and Zamudio K. R. 2005 Species account: Ambystoma maculatum. In Amphibian declines: the conservation status of United States species (ed. M. J. Lannoo), pp. 621-627. University of California Press, Berkeley, USA.

Savage W. K., Fremier A. K. and Shaffer H. B. 2010 Landscape genetics of alpine Sierra Nevada salamanders reveals extreme population subdivision in space and time. Mol. Ecol. 19, 33013314.

Semarnat 2010 Norma Oficial Mexicana NOM-059-SEMARNAT-2010, Protección ambiental-Especies nativas de México de flora y fauna silvestres-Categorías de riesgo y especificaciones para su inclusión, exclusión o cambio-Lista de especies en riesgo. Diario Oficial de la Federación, 10 diciembre 2010, México.

Semlitsch R. D. 2008 Differentiating migration and dispersal processes for pond-breeding amphibians. J. Wildl. Manag. 72, 260-267.

Shaffer B., Huacaz D., Flores-Villela O., Parra-Olea G., Wake D. and Papenfuss T. 2008 Ambystoma altamirani. The IUCN Red List of Threatened Species (Online, 11 September 2013).

Spear S., Peterson F. C. R., Matocq M. D. and Storfer A. 2005 Landscape genetics of the blotched tiger salamander (Ambystoma tigrinum melanostictum). Mol. Ecol. 14, 25532564.

Storfer A., Eastman J. M. and Spear S. F. 2009 Modern methods for amphibian conservation. BioScience 59, 559-571.

Sunny A., Monroy-Vilchis O., Fajardo V. and Aguilera-Reyes U. 2014a Genetic diversity and structure of an endemic and critically endangered stream river salamander (Caudata: Ambystoma leorae) in México. Conserv. Genet. 15, 49-59.

Sunny A., Monroy-Vilchis O., Reyna-Valencia C. and ZarcoGonzález M. 2014b Microhabitat types promote the genetic structure of a microendemic and critically endangered mole salamander (Ambystoma leorae) of central México. PLoS One $9,1-11$.

Sunny A., Monroy-Vilchis O., Zarco-González M. M., Mendoza-Martínez G. D. and Martínez-Gómez D. 2015 
Genetic diversity and genetic structure of an endemic Mexican Dusky Rattlesnake (Crotalus triseriatus) in a highly modified agricultural landscape: implications for conservation. Genetica 143, 705-716.

Sunny A., González-Fernández A. and D’Addario M. 2017 Potential distribution of the endemic imbricate alligator lizard (Barisia imbricata imbricata) in highlands of central Mexico. Amphibia-Reptilia 38, 225-231.

Tennessen J. A. and Zamudio K. R. 2003 Early-male reproductive advantage multiple paternity and sperm storage in an amphibian aggregate breeder. Mol. Ecol. 12, 1567-1576.

Tyler T., Liss W. J., Ganio L. M., Larson G. L., Hoffman R., Deimling E. and Lomnicky G. 1998 Interaction between introduced trout and larval salamanders (Ambystoma macrodactylum) in high-elevation lakes. Conserv. Biol. 12, 94-105.

Van den Berg A. H., McLaggan D., Diéguez-Uribeondo J. and Van West P. 2013 The impact of the water moulds Saprolegnia diclina and Saprolegnia parasitica on natural ecosystems and the aquaculture industry. Fungal Biol. Rev. 27, 33-42.

Van Oosterhout C., Hutchinson W. F., Wills D. P. M. and Shipley P. 2004 MICRO-CHECKER: software for identifying and correcting genotyping errors in microsatellite data. Mol. Ecol. Notes 4, 535-538.

Vázquez-Domínguez E., Mendoza-Martínez A., Orozco-Lugo L. and Cuarón A. D. 2013 High dispersal and generalist habits of the bat Artibeus jamaicensis on Cozumel Island, Mexico: an assessment using molecular genetics. Acta. Chiropt. 15, 411421.

Vences M. and Wake D. B. 2007 Speciation species boundaries and phylogeography of amphibians. In Amphibian biology (ed. H. Heatwole and M. Tyler), pp. 2613-2669. Surrey Beatty and Sons, Chipping Norton, Australia.

Vucetich J. A. and Waite T. A. 2000 Is one migrant per generation sufficient for the genetic management of fluctuating populations? Anim. Conser. 3, 261-266.
Wang I. J. and Summers K. 2010 Genetic structure is correlated with phenotypic divergence rather than geographic isolation in the highly polymorphic strawberry poison-dart frog. Mol. Ecol. 19, 447-458.

Wang I. J., Savage W. K. and Shaffer H. B. 2009 Landscape genetics and least-cost path analysis reveal unexpected dispersal routes in the California tiger salamander (Ambystoma californiense). Mol. Ecol. 18, 1365-1374.

Weir B. S. and Cockerham C. C. 1984 Estimating F-statistics for the analysis of population structure. Evolution38, 1358-1370.

Weisrock D. W., Shaffer H. B., Storz L., Storz S. R. and Voss R. S. 2006 Multiple nuclear gene sequences identify phylogenetic species boundaries in the rapidly radiating clade of Mexican ambystomatid salamanders. Mol. Ecol. 15, 2489-2503.

Welsh H. H., Pope K. L. and Boiano D. 2006 Sub-alpine amphibian distributions related to species palatability to non-native salmonids in the Klamath Mountains of northern California. Divers. Distrib. 12, 298-309.

Werner E. E. and Anholt B. R. 1996 Predator-induced behavioural indirect effects: consequences to competitive interactions in anuran larvae. Ecology 77, 157-169.

Wilson L. D., Johnson J. D. and. Mata-Silva V. 2013 A conservation reassessment of the amphibians of Mexico based on the EVS measure. Amphib. Reptile Conserv. 7, 97-127.

Woinarski J. C. Z. and Ash A. J. 2002 Responses of vertebrates to pastoralism, military land use and landscape position in an Australian tropical savanna. Austral. Ecol. 27, 311-323.

Zambrano L., Valiente E. and Vander Zanden M. J. 2010 Food web overlap among native axolotl (Ambystoma mexicanum) and two exotic fishes: carp (Cyprinus carpio) and tilapia (Oreochromis niloticus) in Xochimilco, Mexico City. Biol. Invasions 12, 3061-3069.

Zamudio K. R. and Wieczorek A. M. 2007 Fine-scale spatial genetic structure and dispersal among spotted salamander (Ambystoma maculatum) breeding populations. Mol. Ecol. 16, 257-274.

\section{Corresponding editor: INDRAJIT NANDA}

